\title{
Layanan referensi sebagai representasi perpustakaan perguruan tinggi
}

\author{
Irwin Pratama Putra1, Indira Irawati ${ }^{2}$ \\ 1,2 Program Studi Ilmu Perpustakaan Universitas Indonesia \\ Jalan Prof. Dr. Selo Soemardjan Kampus Universitas Indonesia Depok 16424, Indonesia \\ E-mail: 1irwin.pratama@ui.ac.id, 2sindirairawati@yahoo.com
}

Received: Agustus 2017; Accepted: Juni 2018; Published: Juni 2018

\begin{abstract}
This study discusses whether the reference service owned by the Universitas Indonesia (UI) Library can be used as a representation of other college libraries. This representation can be seen based on user perception in the University of Indonesia Library of the reference service and also seen from the strategy undertaken by the University of Indonesia Library in improving the quality of their reference service. This research is a qualitative research using case study method. The results of this study indicate that the reference service Library University of Indonesia can be used as a representation of the library of universities, because the University of Indonesia Library managed to make their reference services become more active and more innovative by bringing various innovations in it to get closer to the user. In addition, users also express their opinions regarding reference services in the University of Indonesia Library, this will further strengthen the purpose of this research is a reference service as a representation of the University of Indonesia Library. It is expected that with the innovation made by UI Library to its reference service will make the reference service become the representation of the library itself especially from the user side, because the representation of the reference service is very important to realize the main purpose of university in Indonesia known as Tri Dharma Perguruan Tinggi is education, research and community service.
\end{abstract}

Keywords: Reference service; Library; College library

\begin{abstract}
Abstrak
Penelitian ini membahas mengenai apakah layanan referensi yang dimiliki oleh Perpustakaan Universitas Indonesia (UI) dapat dijadikan sebagai representasi dari perpustakaan perguruan tinggi lainnya. Representasi ini dapat dilihat berdasarkan persepsi pengguna di perpustakaan UI terhadap layanan referensi tersebut dan juga dapat dilihat dari strategi yang dilakukan oleh pihak Perpustakaan UI dalam meningkatkan kualitas layanan referensi yang mereka miliki. Penelitian ini adalah penelitian kualitatif dengan menggunakan metode studi kasus. Hasil dari penelitian ini menunjukan bahwa layanan referensi yang ada di Perpustakaan UI dapat dijadikan sebagai representasi dari perpustakaan perguruan tinggi lainnya, karena Perpustakaan UI berhasil membuat layanan referensi mereka menjadi lebih aktif dan lebih inovatif dengan menghadirkan berbagai macam inovasi di dalamnya untuk lebih mendekatkan diri dengan para pengguna mereka. Selain itu pengguna juga mengutarakan pendapat mereka terkait dengan layanan referensi yang tersedia di Perpustakaan UI, hal ini akan semakin menguatkan tujuan dari penelitian ini yaitu layanan referensi sebagai representasi dari Perpustakaan UI. Diharapkan dengan adanya inovasi yang dilakukan oleh Perpustakaan UI terhadap layanan referensinya akan membuat layanan referensi tersebut menjadi representasi dari perpustakaan itu sendiri terutama dari sisi penggunanya, karena representasi dari layanan referensi ini sangat lah penting untuk mewujudkan tujuan utama perguruan tinggi di Indonesia yang dikenal dengan sebutan Tri Dharma Perguruan Tinggi yaitu pendidikan, penelitian dan pengabdian masyarakat.
\end{abstract}

Kata Kunci: Layanan referensi; Perpustakaan; Perpustakaan perguruan tinggi 


\section{PENDAHULUAN}

Layanan referensi merupakan layanan yang memiliki fungsi tersendiri di suatu perpustakaan (Fritch \& Madernak, 2001). Layanan referensi merupakan suatu layanan penting yang dimiliki oleh perpustakaan yang berfungsi untuk mempermudah pengguna dalam hal pencarian atau penelusuran informasi yang sesuai dengan kebutuhannya. Pada dasarnya, layanan referensi ini berada di dalam perpustakaan dan menunggu pengguna datang untuk memanfaatkan layanan tersebut. Namun, seiring dengan berkembangnya teknologi seperti sekarang ini, layanan referensi di suatu perpustakaan perlu dikembangkan terutama bagi perpustakaan perguruan tinggi.

Dewasa ini informasi mudah untuk diakses kapan pun, di mana pun dan oleh siapa pun. Semua orang dapat mengakses berbagai macam informasi melalui gadget yang mereka miliki melalui situs mesin pencari seperti google, yahoo, dan sebagainya dengan bantuan koneksi internet. Kemudahan dalam mengakses banyaknya informasi tersebut menyebabkan mereka sulit mendapatkan informasi yang sesuai dengan kebutuhan mereka. Hal ini disebabkan karena banyaknya informasi sampah yang tersebar di internet, namun tak sedikit juga ada informasi yang bermanfaat di dalamnya. Pada bidang pendidikan, informasi menjadi pondasi utama bagi kegiatan sivitas akademik khususnya dalam bidang penelitian. Sulitnya mencari informasi yang valid, relevan, dan mutakhir menjadi hambatan bagi para penelusur informasi terutama di dalam lingkungan akademik. Banyaknya informasi di internet menyebabkan orang mengalami kesulitan untuk mendapatkan informasi yang sesuai dengan kebutuhannya, selain itu meluapnya informasi juga menyebabkan mereka menjadi kesulitan dalam mengolah informasi tersebut. Oleh sebab itu pengembangan perpustakaan perlu dilakukan di dalam suatu perpustakaan untuk menyesuaikan perkembangan teknologi informasi dan komunikasi yang begitu cepat.

Sudah banyak perpustakaan yang memanfaatkan teknologi dan jaringan internet sebagai alat untuk memaksimalkan suatu layanan perpustakaan, termasuk di perpustakaan Universitas Indonesia (UI) yang memanfaatkan teknologi dan internet untuk memaksimalkan keberadaan layanan referensi mereka. Pengembangan terhadap layanan referensi penting dilakukan bagi perpustakaan peruguruan tinggi. Hal ini didukung oleh pernyataan dari Luini dalam Rahmi (2016) yang menyatakan bahwa dengan adanya perkembangan teknologi informasi dan komunikasi membuat perpustakaan harus lebih inovatif dalam memenuhi kebutuhan pemustaka dengan cara yang efektif dan efisien. Salah satu caranya adalah dengan membuat inovasi pada layanan referensi mereka agar menjadi representasi dari perpustakaan perguruan tinggi.

Perpustakaan di Indonesia biasa direpresentasikan dalam bentuk gambar perpustakaan, koleksi perpustakaan, komputer dan jaringannya serta pengguna perpustakaan (Gani, 2010). Perpustakaan UI saat ini merupakan salah satu perpustakaanyang memiliki gedung sangat megah serta koleksi yang cukup lengkap. Namun tidak hanya lengkap dari segi koleksi dan fasilitas saja, tapi Perpustakaan UI juga memiliki layanan referensi yang 
diharapkan juga dapat menjadi representasi dari perpustakaan itu sendiri. Diharapkan dengan adanya inovasi yang dilakukan oleh Perpustakaan UI terhadap layanan referensinya akan membuat layanan referensi tersebut menjadi representasi dari perpustakaan itu sendiri terutama dari sisi penggunanya, karena representasi dari layanan referensi ini sangatlah penting untuk mewujudkan tujuan utama perguruan tinggi di Indonesia yang dikenal dengan sebutan Tri Dharma Perguruan Tinggi yaitu pendidikan, penelitian dan pengabdian masyarakat.

Adapun rumusan masalah pada penelitian ini yaitu apakah layanan referensi dapat dijadikan sebagai representasi dari perpustakaan perguruan tinggi berdasarkan persepsi pengguna di Perpustakaan UI? Tujuan penelitian ini yaitu untuk mengetahui apakah layanan referensi di Perpustakaan UI dapat dijadikan sebagai representasi dari perpustakaan perguruan tinggi lainnya,dan juga untuk mengetahui pendapat pemustaka terkait layanan referensi di Perpustakaan UI.

\section{METODE PENELITIAN}

Penelitian ini menggunakan pendekatan penelitian kualitatif. Penelitian kualitatif dilakukan jika ada masalah yang belum jelas. Penelitian kualitatif bisa dikatakan juga sebagai penelitian yang dilakukan secara alamiah dan bersifat temuan. Alasan memilih pendekatan kualitatif adalah untuk mendapatkan hasil yang komperhensif dan rinci terkait layanan referensi di Perpustakaan UI.

Creswell (2010) mengatakan bahwa studi kasus merupakan strategi penelitian di mana di dalamnya peneliti menyelidiki secara cermat suatu program, peristiwa, aktivitas, proses, atau sekelompok individu. Yin (2011) mengatakan studi kasus adalah sebuah penyelidikan empiris yang menginvestigasi fenomena kontemporer dalam konteks kehidupan nyata, khususnya ketika batas antara fenomena dan konteks tidak begitu jelas.

Ary dalam Idrus (2009) studi kasus adalah suatu penyelidikan intensif tentang seorang individu, namun studi kasus terkadang dapat juga dipergunakan untuk menyelidiki unit sosial yang kecil seperti keluarga, sekolah, kelompok-kelompok "geng" anak muda.

Tujuan penggunaan penelitian studi kasus menurut Yin (2011) adalah untuk menjelaskan bagaimana keberadaan dan mengapa kasus tersebut terjadi. Penelitian studi kasus bukan sekedar menjawab pertanyaan penelitian tentang 'apa' (what) obyek yang diteliti, tetapi lebih menyeluruh dan komprehensif lagi adalah tentang 'bagaimana' (how) dan 'mengapa' (why).

Penelitian ini dilakukan di Perpustakan UI, khususnya pada layanan referensi dengan objek penelitiannya adalah pustakawan serta pemustaka Perpustakaan UI. Penelitian ini dilakukan pada Maret hingga Juni 2017 dengan menggunakan panduan wawancara sebagai instrumen penelitiannya.

Teknik pengumpulan data dilakukan dengan cara wawancara mendalam, observasi, serta studi dokumentasi. Teknis analisis data dilakukan dengan mengkoleksi data terlebih dahulu, kemudian mereduksi data yang tidak sesuai agar diperoleh data yang rinci dan tepat. Setelah itu dilakukan penyajian data yang telah diolah sedemikian rupa untuk 
akhirnya diverifikasi atau dibuat suatu kesimpulan.

\section{HASIL DAN PEMBAHASAN}

Tyasmara (2016) dalam penelitiannya menyatakan bahwa untuk menjadikan layanan referensi sebagai representasi perpustakaan perguruan tinggi bukanlah hal yang mudah, dibutuhkan strategi kerja sama dan sinergi dari berbagai pihak agar tujuan tersebut dapat terlaksana. Kerja sama ini dilakukan terutama dalam hal pengembangan repositori institusi, kerja sama dengan bidangInformation Technology (IT) dan kerja sama untuk mempromosikan layanan referensi yang dilakukan oleh pustakawan dengan pihak lain. Strategi kerja sama tersebut sudah dilakukan oleh Perpustakaan UI dengan menghadirkan berbagai inovasi yang bertujuan untuk lebih mendekatkan diri kepada pengguna sehingga pengguna menjadi tahu dan memanfaatkan layanan referensi tersebut. Selain strategi kerja sama, Perpustakaan UI juga berupaya untuk selalu meningkatkan kompentensi yang dimiliki oleh pustakawan referensi di sana dengan menyediakan berbagai pelatihan yang wajib diikuti oleh pustakawan referensi di Perpustakaan UI.

Salah satu cara agar layanan referensi menjadi representasi dari perpustakaan perguruan tinggi adalah perpustakaan harus melakukan kerja sama dengan berbagai pihak dan hal itu sudah dilakukan oleh Perpustakaan UI berdasarkan hasil wawancara dengan koordinator layanan di sana. Koordinator layanan mengatakan bahwa layanan referensi Perpustakaan UI memiliki mitra atau kerja sama dengan perpustakaan lain. Mitra tersebut antara lain Forum perpustakaan Perguruan Tinggi
Indonesia (FPPTI), forum antar pustakawan yaitu Ikatan Sarjana Ilmu perpustakaan dan Informasi Indonesia (ISIPII) dan Forum Media Komunikasi yang di mana mereka memiliki grup whatsapp sebagai media untuk berkomunikasi satu sama lain. Setiap forum atau grup ini beranggotakan pustakawan di berbagai universitas di Indonesia. Forum ini akan membantu jika ada pengguna yang mencari sumber informasi yang cukup sulit dan pustakawan referensi tidak dapat menemukannya, maka pustakawan referensi di Perpustakaan UI dapat melemparkan permintaan pengguna tersebut ke forum dan grup tersebut. Tujuannya agar semua anggota dapat saling membantu dalam pencarian informasi yang dibutuhkan oleh pengguna. Sehingga pengguna mendapatkan informasi yang dia inginkan dengan cepat dan sesuai.

Koordinator layanan Perpustakaan UI mengatakan bahwa layanan referensi Perpustakaan UI saat ini telah melakukan kerja sama dengan para ahli di bidang IT untuk membuat inovasi terbaru dari layanan referensi mereka. Beliau melanjutkan bahwa dalam waktu dekat ini Perpustakaan UI akan meluncurkan layanan K-ATM yang sudah dikembangkan dan juga pembuatan UI ANA Digital Program. Pembuatan Knowledge Automated Teller Machine (K-ATM) dan Akses Unggah Karya Ilmiah (UIANA) Digital Program merupakan inovasi yang dibuat oleh layanan referensi Perpustakaan UI agar dapat mempermudah pengguna dalam hal ini adalah mahasiswa UI dengan memanfaatkan teknologi yang sudah berkembang.

Perpustakaan UI berencana akan meluncurkan K-ATM yang sudah dikembangkan kembali dari segi konten, 
fitur dan titik aksesnya. Layanan K-ATM ini dibangun atas kerja sama Perpustakaan UI dengan Direktorat Sistem Teknologi Informasi. Hal tersebut sesuai dengan yang dikatakan oleh Tyasmara (2016) yang mengatakan bahwa hal terpenting untuk menjadikan layanan referensi sebagai representasi dari perpustakaan perguruan tinggi adalah dengan melakukan upaya kerja sama dan sinergi yang menyeluruh dari berbagai pihak, salah satu contohnya kerja sama di bidang IT.

Menurut pustakawan referensi, K-ATM berisi beberapa e-book dan e-article yang berasal dari hasil pencarian mereka selama melayani layanan referensi kepada pengguna.

“... kalau untuk kontennya sih K-ATM ini berasal dari data elektronik yang dikumpulkan oleh teman-teman pustakawan referens di sini, kita kan selalu mengirimkan literatur untuk para profesor tuh, nah konten yang sudah kami kumpulkan kami transfer juga ke K-ATM. Jadi K-ATM tidak akan dapat berjalan kalau kita tidak mencarikan sumber sebelumnya" (Melati, wawancara, Februari 5, 2017)

"K-ATM itu layanan referens dari segi kontennya, tidak hanya e-book, tapi juga e-journal yang berasal dari hasil pencarian kami di layanan EDS setiap bulannya, karena kan kita selalu rutin mengirimkan jurnal kepada guru besar dan para pimpinan, lalu hasil pencarian tersebut kami jadikan konten di K-ATM juga" (Mawar, wawancara, Februari 5, 2017)

Pernyataan di atas sesuai dengan yang diungkapkan oleh Tyasmara (2016) bahwa pada kerja sama dengan bidang IT, perpustakaan dapat membuat suatu database yang berisi pertanyaan-pertanyaan pengguna di layanan referensi kemudian mengembangkan konten yang berisi hasil pencarian. Hal ini dapat berfungsi sebagai salah satu preservasi pengetahuan pustakawan terhadap layanan yang telah diberikan oleh pengguna.

K-ATM juga akan ditambahkan fitur statistik pengunjung, fitur ini hanya dapat diakses oleh pengembang untuk melihat keterpakaian K-ATM. Selanjutnya penambahan fitur mobile, penambahan fitur ini diharapkan agar mahasiswa UI dapat mengakses K-ATM melalui gadget yang mereka miliki sebagai pengunjung virtual. Sselain itu K-ATM juga akan dikembangkan titik aksesnya, dari yang sebelumnya K-ATM hanya ada di depan dan di samping BNI, serta di Fakultas Ilmu Pengetahuan Budaya (FIB), kini akan diperluas di pelbagai fakultas di UI.

Kerja sama yang dilakukan oleh layanan referensi dengan bidang IT berikutnya adalah pembuatan UIANA Digital Program. UIANA Digital Program berisi konten skripsi, disertasi dan naskah full text yang dapat dibaca langsung di monitor komputer namun tidak dapat diunduh. Koordinator layanan Perpustakaan UI mengatakan bahwa program ini rencananya akan dilaksanakan pada tahun 2017 ini yaitu dengan mengolah koleksi UIANA dengan cara digitalisasi yang jumlahnya ditaksir mencapai dua ribu koleksi ditambah monitor layar sentuh sebanyak 5 buah. Program ini akan memudahkan pengguna karena pengguna tidak harus mengunjungi rak dan tidak perlu khawatir koleksi tersebut sedang dibaca oleh pengguna lain saat mencari koleksi skripsi, tesis dan disertasi di ruang koleksi UIANA. 
Selain memiliki kerja sama di bidang IT, Koordinator layanan mengatakan bahwa Perpustakaan UI juga bekerja sama dengan bidang repositori institusi dalam hal pengadaan konten, format tampilan dan juga kemudahan akses yang akan diberikan kepada pengguna.

"Kalau untuk kerja sama dengan bagian repositori institusi sih kami biasanya memberikan masukan kepada pengelola repositori dalam hal pengisian konten, format tampilan dan kemudahan akses ya". (Kamboja, wawancara, Februari 5, 2017)

Pernyataan tersebut sesuai dengan yang dikatakan oleh Tyasmara (2016) yang menyatakan bahwa pustakawan referensi harus bekerja sama dengan bagian repositori institusi untuk dapat menjaga aset intelektual (hasil penelitian) yang dimiliki universitas dengan usaha preservasi dan meningkatkan prestige institusinya. Hal ini penting dilakukan karena saat ini perpustakaan sudah semakin maju dengan menerbitkan koleksi dalam bentuk digital.

Tidak hanya bekerja sama dengan bidang IT dan repositori institusi, Perpustakaan UI juga bekerja sama dengan berbagai fakultas dalam melakukan promosi layanan referensi mereka. Hal ini diungkapkan oleh pustakawan referensi Perpustakaan UI yang menyatakan bahwa Perpustakaan UI telah bekerja sama dengan fakultas dan departemen untuk melakukan roadshow perpustakaan ke berbagai fakultas atau program studi yang ada di UI. Beliau melanjutkan bahwa roadshow perpustakaan ini kegiatannya tidak hanya promosi tentang perpustakaan dan layanan yang dimiliki perpustakaan saja, melainkan juga melakukan kegiatan pelatihan Literasi Informasi.

"Kalau dari segi promosi sih biasanya kami bekerja sama dengan fakultas dengan departmen dengan cara melakukan

roadshowperpustakaanmisalnya" (Mawar, wawancara, Februari 5, 2017)

“..roadshownya ini kegiatannya meliputi pelatihan literasi informasi juga, jadi tidak hanya promosi perpustakaan, tapi juga memberi pelatihan tentang literasi informasi kepada pengguna" (Mawar, wawancara, Februari 5, 2017)

Pernyataan tersebut sesuai dengan yang diungkapkan oleh Tyasmara yang menyatakan bahwa pustakawan referensi dapat bekerja sama dengan pihak lain dalam mempromosikan kepada pengguna bahwa di perpustakaan terdapat layanan referensi yang dapat membantu pengguna dalam melakukan penelusuran informasi dan bimbingan personal terkait kebutuhan informasi mereka (Tyasmara, 2016).

Strategi kerja sama yang telah disebutkan di atas merupakan upaya untuk mewujudkan suatu inovasi yang dibuat oleh Perpustakaan UI yang di mana tujuannya adalah untuk memenuhi setiap kebutuhan pemustaka dengan melihat adanya perubahan teknologi informasi yang di mana kebutuhan informasi mereka juga sudah berubah. Menurut koordinator layanan, jika suatu perpustakaan tidak melakukan inovasi, maka perpustakaan perguruan tinggi di mana pun pasti sudah ditinggalkan penggunanya. Selain itu pengguna juga dapat berkonsultasi dengan pustakawan referensi UI tanpa harus bertemu langsung. 
Selain harus melakukan kerja sama dengan berbagai pihak, layanan referensi sebagai representasi dari perpustakaan perguruan tinggi juga dapat dilihat dari bagaimana strategi perpustakaan dalam meningkatkan kompetensi yang dimiliki oleh pustakawan referensi di perpustakaan perguruan tinggi dalam hal melayani penggunanya (blended librarianship). Reference and User Services Association (RUSA) memberikan kompetensi yang harus dimiliki oleh pustakawan referensi, seperti Akses, Dasar Pengetahuan, Pemasaran, kesiapan dan penyampaian, Kolaborasi dan Evaluasi sumber daya dan layanan.

Dari sisi akses, pustakawan referensi di Perpustakaan UI selalu menanyakan kebutuhan informasi pengguna secara mendalam melalui layanan penelusuran informasi di lantai 3 Perpustakaan UI.

"hmm kalau saya sih biasanya kalau misalnya ada yang datang, saya selalu bertanya dari jurusan apa, ingin mencari informasi tentang apa, apakah anda sudah mengetahui online database Perpustakaan UImembership dan non membership" (Mawar, wawancara, Februari 5, 2017)

Pernyataan tersebut sesuai yang diungkapkan dalam RUSA bahwa Pustakawan referensi harus mengetahui setiap kebutuhan informasi pengguna serta mengembangkan keterampilan untuk memenuhi kebutuhan pengguna tersebut (RUSA, 2010).

Dari sisi dasar pengetahuan, pustakawan referensi di Perpustakaan UI dipastikan sudah mengetahui bagaimana cara mengakses online database yang dilanggan oleh perpustakaan, karena pustakawan referensi selalu diberikan sosialisasi oleh vendor penyedia jurnal yang dilanggan oleh Pepustakaan UI dalam hal mengakses jurnal mereka.

"Kita biasanya pelatihan tentang gimana sih tentang sosialisasi penggunaan online database kayak proquest, ebsco dan lain lain. Biasanya pelatihan diberikan langsung dari pihak vendor yang memberikan sosialisasi tentang bagaimana cara menggunakan online database mereka, pelatihan ini sifatnya lebih ke peningkatan skill kami dalam menggunakan online database agar dapat diajarkan ke pengguna nantinya" (Melati, wawancara, Februari 5, 2017)

Setelah melakukan pelatihan dengan pihak vendor, pustakawan referensi mengajarkan hasil dari pelatihan yang mereka dapatkan sebelumnya kepada mahasiswa melalui kegiatan Literasi Informasi. Pustakawan referensi akan mengajarkan kepada para mahasiswa terkait bagaimana cara menelusur informasi di online database yang di langgan oleh Perpustakaan UI, selain itu bagaimana cara menelusur informasi yang baik di google melalui teknik boolean logic, dan juga pustakawan referensi memberikan pelatihan terkait bahaya plagiarisme juga kepada mahasiswa.

"Literasi Informasi ini sih lebih ke mengajarkan bagaimana mencari literatur melalui online database, kalau ada mahasiswa jurusan teknik mesin misalnya ya saya memberi pelatihan tentang bagaimana cara menelusur melalui online database yang berisi sumber teknik mesin, seperti itu" (Melati, wawancara, Februari 5, 2017) 
“Kalau Literasi Informasi ini sih luas ya, seperti pendidikan pemakai itu dasar diajarkan sewaktu orientasi belajar mahasiswa (OBM), kemudian tahapan menengahnya bagaimana cara menggunakan online database, jenis online database apa saja. Kalau khusus tahun kemarin literasi informasi kita mulai meningkat dengan mengajarkan tentang bagaimana penggunaan bolean logic, antisipasi plagiarisme itu juga termasuk ke dalam Literasi Informasi" (Mawar, wawancara, Februari 5, 2017)

Pernyataan di atas sesuai yang diungkapkan dalam RUSA bahwa Pustakawan referensi harus memiliki dasar pengetahuan mengenai katalog online, sistem penelusuran, database, situs web, pola penelusuran informasi dan perilaku pengguna, pengaruh teknologi terhadap struktur informasi, hak cipta dan undangundang HAKI serta standar kemampuan informasi lainnya (RUSA, 2010).

Dari sisi kolaborasi, pustakawan referensi di Perpustakaan UI saling bekerja sama dalam hal memenuhi kebutuhan informasi pengguna mereka. Tidak hanya antar pustakawan referensi, tetapi mereka juga bekerja sama dengan pustakawan lain seperti pustakawan sirkulasi dan pustakawan yang ahli di bidang IT (blended librarian). Koordinator layanan Perpustakaan UI mengatakan bahwa pustakawan referensi di Perpustakaan UI saat ini memiliki beberapa pustakawan yang dapat disebut sebagai blended librarian. Koordinator layanan Perpustakaan UI mengatakan bahwa pustakawan referensi yang ada di lantai 3 semuanya dapat dikatakan sebagai blended librarian karena mereka tidak hanya ahli di bidang kepustakawanan tetapi juga ahli di bidang IT.
Koordinator layanan Perpustakaan UI melanjutkan bahwa pustakawan referensi di Perpustakaan UI dapat dikatakan sebagai blended libraian karena mereka juga melakukan pengajaran dalam memberikan literasi informasi kepada pengguna perpustakaan yang ingin belajar mengenai cara penulisan karya ilmiah yang baik dan benar. Pernyataan tersebut sesuai dengan yang diungkapkan oleh Tyasmara (2016) bahwa blended librarian dapat menerapkan teknologi untuk meningkatkan pengajaran dan pembelajaran yang diterapkan saat melakukan proses belajar-mengajar di kelas Literasi Informasi. Pernyataan di atas juga sesuai yang diungkapkan dalam RUSA (2010) bahwa pustakawan referensi harus melakukan kolaborasi atau bekerja sama dengan kolega, organisasi informasi, agensi dan kelompok lain untuk meyakinkan pengguna saat mendapatkan layanan yang mereka butuhkan.

Terakhir dari sisi evaluasi sumber daya dan layanan, Koordinator Layanan Perpustakaan UI mengatakan bahwa Perpustakaan UI memiliki pustakawan referensi dengan latar belakang pendidikan minimal S2 Ilmu perpustakaan. Jadi dari sisi sumber daya dan layanan sudah tidak diragukan lagi kualitasnya dalam memberikan informasi yang relevan kepada pengguna. Pernyataan tersebut sesuai yang diungkapkan dalam RUSA bahwa evaluasi terhadap sumber daya dalam konteks kebutuhan informasi sangat penting dalam rangka menjaga agar layanan informasi tetap relevan (RUSA, 2010).

Berdasarkan hasil wawancara dengan beberapa informan, peneliti telah mengintepretasi jawaban dari pengguna di Perpustakaan UI berdasarkan persepsi mereka terhadap eksistensi layanan 
referensi di sana dan juga berdasarkan tujuan mereka datang ke perpustakaan. Hal ini sejalan dengan teori yang diungkapkan oleh (Suharman, 2005) yang menyatakan bahwa persepsi merupakan suatu proses menginterpretasikan dan menafsirkan informasi yang diperoleh seseorang melalui sistem panca indera (Suharman, 2005). Berdasarkan teori ini lah peneliti mengintepretasikan setiap kata-kata yang mereka ucapkan melalui mulut dan gerak tubuh mereka terkait keberadaan layanan referensi di Perpustakaan UI.

Hasilnya menyatakan bahwa pengguna dalam hal ini adalah mahasiswa UI tidak mengetahui apa itu layanan referensi, namun mereka mengetahui kalau di Perpustakaan UI terdapat layanan seperti K-ATM, layanan situs perpustakaan, dan layanan mengunduh jurnal di remote lib, yang di mana layanan tersebut sebenarnya termasuk bagian dari layanan referensi. Contoh konkritnya pada saat OBM (Orientasi Belajar Mahasiswa) mahasiswa UI tidak pernah diperkenalkan kalau layanan seperti K-ATM, layanan penelusuran informasi dan layanan lainnya adalah layanan referensi, namun mereka lebih diperkenalkan bahwa di Perpustakaan UI terdapat layanan-layanan tersebut.

“Kalau K-ATM saya tahu, tapi belum pernah menggunakannya. Layanan itu pernah dikenalkan sewaktu OBM sama petugas perpustakaan gitu. Beliau memperkenalkan kalau ini adalah KATM yang berisi buku dalam bentuk digital dan cara penggunaannya cukup mudah, kita tinggal memilih buku apa yang kita inginkan, lalu buku tersebut akan dikirim ke e-mail" (Raput, wawancara, Maret 9, 2017) "oh ituu.. Iya saya tau tapi saya gak tau fungsinya buat apa.." (Mahli, wawancara, Maret 9, 2017)

“Oohh yang ada di bawah itu ya? Gue tahu tapi gue gatau itu buat apa.." (Ida, wawancara, Maret 10, 2017)

"Tahu tapi tidak pernah pakai" (Rimka, wawancara, Maret 10, 2017)

"Kalo K-ATM mah saya tau, itu ada juga di FIB kan?" (Icad, wawancara, Maret 9, 2017)

“Wah dapat bantu nyariin referensi? Enak banget dong haha iya saya baru tau karena saya juga jarang ke perpustakaan juga sih makanya saya ngga tau. Itu letaknya ada di mana layanan itu?." (Icad, wawancara, Maret 9, 2017)

Selanjutnya, berdasarkan temuan lain yang didapat dari penelitian ini, pengguna mengatakan bahwa layanan referensi yang paling sering mereka gunakan di Perpustakaan UI adalah layanan situs perpustakaan di www.lib.ui.ac.id dan situs penelusuran jurnal di www.remotelib.ui.ac.id. Hal ini sesuai dengan yang diungkapkan oleh informan dalam penelitian ini.

“Lebih ke layanan situs perpustakaan yang diakses lewat iMac itu sih, di sana saya biasa nyari judul buku yang sesuai dengan apa yang saya mau.." (Mahli, wawancara, Maret 9, 2017)

"Biasanya kalau saya sih mencari sumber di remote lib, tapi saya biasanya suka nyari penelitian sebelumnya dulu yaitu skripsinya senior di situs perpustakaan. Makanya hari ini saya ke perpustakaan untuk membuat akun dan tujuannya untuk mendownload beberapa skripsi senior saya" (Yara, wawancara, Maret 9, 2017) 
"Lebih ke layanan lib.ui.ac.id siih" (Ida, wawancara, Maret 10, 2017)

"Oh iya kalau situs perpustakaan mah itu mah hampir setiap saya datang kesini, karena saya mencari judul skripsi dan tesis dari website itu dulu sebelum saya pergi mencari di rak" (Rimka, wawancara, Maret 10, 2017)

"Ya itu saya biasanya ke lantai 2 buat nyari buku teks, trus lantai 3 buat nyari referensi skripsi senior, sama pakai remote lib aja" (Icad, wawancara, Maret 9, 2017)

Keberadaan layanan Literasi Informasi atau pendidikan pemakai juga sudah diketahui pengguna pada saat mereka mengikuti OBM di semester satu. Hal tersebut dapat dilihat dari apa yang dikatakan oleh informan dalam penelitian ini bahwa pada saat mereka mengikuti OBM di semester awal, mereka diperkenalkan beberapa layanan yang ada di Perpustakaan UI serta bagaimana cara menggunakan layanan tersebut.

“..saya inget sih dulu pas OBM, tapi saya ngga tahu nama layanannya" (Raput, wawancara, Maret 9, 2017)

“Ooh iya inget gue, tapi layanannya ngga langsung gue gunakan, dan gue juga belum dapat bedain ada apa aja layanan yang ada di perpus UI" (Yara, wawancara, Maret 9, 2017)

"Ohh kalau itu gue masih inget dulu waktu OBM kita dikasih materi IL untuk mengetahui layanan-layanan yang ada di perpus UI kan" (Yara, wawancara, Maret 9, 2017)

"Oh ituu saya inget tuh jadi kita dikasih materi yang isinya perkenalan dari beberapa layanan yang ada di
Perpustakaan UI" (Mahli, wawancara, Maret 9, 2017)

"Ooh ituu iyaiya saya masih inget kok waktu itu pas OBM ada materi itu kan yang ngejelasin Perpustakaan UI" (Icad, wawancara, Maret 9, 2017)

Pernyataan di atas sesuai dengan pernyataan dari Rahmi (2016) bahwa layanan yang diberikan dalam layanan literasi informasi ini adalah untuk membimbing pemustaka agar lebih mengenal Perpustakaan UI secara lebih dalam yang di mana layanan ini awalnya disebut sebagai layanan bimbingan pemakai.

Berdasarkan keseluruhan layanan referensi yang dimiliki oleh Perpustakaan UI, ada beberapa layanan seperti "Layanan Penelusuran Informasi" dan "Layanan Referensi Elektronik" yang belum diketahui oleh pengguna.

"Saya baru tau layanan itu, itu ada di mana letaknya? Saya tidak tahu akan adanya layanan itu .." (Mahli, wawancara, Maret 9, 2017)

"Wah seriusan? sayang banget saya baru tau ada layanan itu.." (Yara, wawancara, Maret 9, 2017)

"Wah gatau tuh saya hehe" (Ida, wawancara, Maret 10, 2017)

"Wah apa tuh? saya tidak tahu hehe" (Rimka, wawancara, Maret 10, 2017)

"Oh ada ya? Saya baru tahu mas" (Raput, wawancara, Maret 9, 2017

“Oalaaah itu jasa penelusuran? Saya kira apaan. Saya ngga pernah tau sebelumnya". (Icad, wawancara, Maret 9, 2017) 
Ketidaktahuan mahasiswa S1 terhadap layanan penelusuran informasi dan layanan referensi elektronik ini menurut pustakawan referensi adalah wajar. Karena menurut pustakawan referensi mahasiswa S1 hanya diperkenalkan dengan layanan perpustakaan sewaktu OBM saja.

"hmm kalau menurut saya kenapa mereka tidak tahu ada layanan referensi ini karena pada saat OBM mereka diperkenalkan layanan-layanan yang ada di Perpustakaan UI masih banyak mahasiswa yang mengabaikan, hal ini menurut saya wajar ya karena mereka kan masih peralihan dari masa SMA ke masa perkuliahan ya jadi ya begitu deh" (Mawar, wawancara, Februari 5, 2017)

Berdasarkan jawaban pengguna di atas, dapat disimpulkan bahwa pengguna sebenarnya telah mengetahui beberapa layanan referensi yang ada di Perpustakaan UI khususnya layanan K-ATM dan Situs perpustakaan dan Literasi Informasi. Namun pengguna juga telah melontarkan alasan mengapa mereka tidak tahu jika di Perpustakaan UI memiliki beberapa layanan referensi lainnya seperti layanan penelusuran informasi, dan layanan referensi elektronik. Sebagian besar dari mereka menyatakan bahwa Perpustakaan UI masih kurang dalam hal mempromosikan layanan tersebut kepada mereka, sehingga mereka tidak tahu akan keberadaan layanan-layanan tersebut.

“..saya baru tau layanan itu dari mas, dan sayang banget kalau layanan itu tidak dipromosikan secara besar-besaran oleh Perpustakaan UI" (Mahli, wawancara, Maret 9, 2017)

“..menurut saya mereka harus lebih memperkenalkan kembali layanan ini ke lingkungan sivitas UI bahwa mereka punya layanan ini sehingga layanan ini dapat terpakai" (Raput, wawancara, Maret 9, 2017)

"Mungkin kalau saya tahu dari awal terkait layanan yang sudah mas sebutkan tadi, itu sangat membantu saya. Intinya kalau menurut saya sih semua layanan yang ada di Perpustakaan UI itu sudah cukup baik bahkan lebih baik dari perpustakaan lain. Namun ya sekali lagi seandainya saya diberi tahu tentang layanan tersebut seperti bagaimana cara mengaksesnya gitu-gitu, pasti akan saya maksimalkan layanan-layanan tersebut.." (Rimka, wawancara, Maret 10, 2017)

“..mungkin mereka harus lebih menambah sosialisasi lagi terkait layanan-layanan yang ada di sana. Khususnya layanan referensi itu. (Yara, wawancara, Maret 9, 2017)

“Hmm gatau sih ya apa karena saya yang jarang ke perpustakaan, atau memang Perpustakaan UI kurang promosinya" (Icad, wawancara, Maret 9, 2017)

Pernyataan pengguna di atas diperkuat oleh pernyataan yang diungkapkan oleh pustakawan referensi Perpustakaan UI yang mengatakan bahwa memang sangat jarang mahasiswa S1 UI yang memanfaatkan layanan penelusuran informasi dan layanan referensi elektronik ini.

"Kalau di sini sih biasanya paling banyak tuh yang datang mahasiswa S2 ya, ada juga S1nya tapi ya gitu kebanyakan yang memanfaatkan layanan kami di sini ratarata mahasiswa S1 di luar UI, kalau mahasiswa S1 UI itu jarang banget pakai layanan kita ini, asumsi saya sih mereka sudah dapat menelusur sendiri ya, 
mungkin" (Melati, wawancara, Februari 5, 2017)

Berdasarkan pernyataan di atas, pengguna merasa kalau Perpustakaan UI harus melakukan sosialisasi kembali terkait layanan referensi mereka kepada mahasiswa UI secara besar-besaran agar layanan ini menjadi lebih eksis dan tingkat keterpakaian layanan ini juga akan bertambah. Karena eksistensi dan penggunaan dari suatu layanan di perpustakaan sangat diperlukan agar layanan yang telah dibuat oleh suatu perpustakaan tidak menjadi sia-sia dan dapat dimanfaatkan semaksimal mungkin oleh penggunanya. Hal tersebut sesuai dengan yang dikatakan oleh Tyasmara (2016) yang mengatakan bahwa perpustakaan harus selalu memutar otak untuk melakukan berbagai inovasi agar layanan referensi di perpusakaan tersebut dapat semakin menonjol dan diketahui oleh penggunanya.

Pernyataan di atas juga didukung oleh pernyataan dari pustakawan referensi yang mengatakan bahwa promosi perpustakaan terhadap layanan referensi ini memang masih sangat kurang. Bahkan hampir tidak ada mahasiswa S1 yang memanfaatkan layanan referensi ini khususnya layanan penelusuran informasi dan layanan referensi elektronik.

"kalau menurut saya mungkin dari segi rambu atau promosi yang dilakukan oleh perpustakaan juga masih kurang ya, jadi orang masih mempertanyakan ini tuh layanan apa sih" (Mawar, wawancara, Februari 5, 2017)

"kalau memang kurang ya mungkin karena promosi yang dilakukan oleh Perpustakaan UI ya hanya melakukan promosi secara keseluruhan bukan khusus tentang layanan referensi" (Melati, wawancara, Februari 5, 2017)

Pernyataan di atas sesuai dengan pendapat dari Rangkuti (2016) yang menyatakan bahwa kurangnya eksistensi atau keberadaan dari suatu layanan referensi di mata pengguna adalah karena kurangnya publikasi yang dilakukan oleh perpustakaan dalam hal mempromosikan layanan mereka. Hal ini lah yang menyebab kan kurangnya tingkat keterpakaian pada suatu layanan perpustakaan (Rangkuti, 2014).

Setelah menggali lebih dalam, berdasarkan hasil wawancara yang dilakukan oleh peneliti kepada mahasiswa UI, hasilnya menunjukan bahwa mereka sebenarnya juga selalu memanfaatkan layanan referensi ketika mereka datang ke Perpustakaan UI. Hal ini juga akan memperkuat bahwa layanan referensi dapat dijadikan sebagai representasi dari Perpustakaan UI. Pernyataan tersebut sesuai dengan apa yang dikatakan oleh Mahli dan Icad selaku pengguna di Perpustakaan UI, Ia mengatakan bahwa tujuannya datang ke Perpustakaan UI adalah untuk mencari referenai dari skripsi seniornya.

"Saya nyari buku bacaan terkait ilmu komputer sambil kepoin skripsi-skripsi senior aja nih sekalian nemenin temen saya anak UGM untuk nyari topik skripsinya dia.." (Mahli, wawancara, Maret 9, 2017)

"Hmm saya lagi nyari skripsi senior nih buat jadiin referensi buat skripsi saya.." (Icad, wawancara, Maret 9, 2017) 
Sejalan dengan penjelasan Mahli dan Icad, Yara juga menuturkan bahwa tujuannya datang ke Perpustakaan UI untuk mengunduh koleksi skripsi di situs perpustakaan dengan meminta username dan password kepada petugas perpustakaantujuan dapat membuka dan mengunduh koleksi skripsi tersebut.

"Kebetulan hari ini saya lagi buat username untuk download skripsi. gitu. Karena kan kalo misalnya kita mau download skripsi gitu di situs lib.ui.ac.id kan harus pakai akun ya, jadi saya mau buat akunnya dulu ini." (Yara, wawancara, Maret 9, 2017)

Pendapat tersebut semakin diperkuat oleh informan selanjutnya yang mengatakan kalau tujuannya datang ke Perpustakaan UI ingin mencari sumber referensi untuk penelitiannya.

"Hmm saya lagi nyari referensi buku sambil ngerjain skripsi aja nih.." (Ida, wawancara, Maret 10, 2017)

\section{Secara eksplisit pengguna}

Perpustakaan UI tidak mengetahui definisi dari layanan referensi di Perpustakaan UI, artinya mereka belum mengetahui bahwa layanan yang sudah mereka ketahui keberadaannya seperti K-ATM, Situs perpustakaan dan sebagainya merupakan layanan referensi. Namun jika dilihat berdasarkan tujuan mereka datang ke Perpustakaan UI, semua informan sepakat menjawab bahwa tujuan mereka datang ke perpustakaan adalah untuk mendapatkan informasi yang sesuai dengan kebutuhan mereka terkait penelitian akhir yang sedang mereka rancang, dan salah satu cara agar mereka mendapatkan informasi yang sesuai dengan kebutuhan mereka adalah dengan cara memanfaatkan layanan referensi yang dimiliki oleh Perpustakaan UI.

Setelah informan mengetahui keberadaan dari semua layanan referensi yang dimiliki oleh Perpustakaan UI, peneliti mulai menjelaskan kepada informan terkait definisi dari masing-masing layanan referensi yang dimiliki oleh Perpustakaan UI. Setelah pengguna memahami tentang layanan referensi yang telah disebutkan peneliti, mereka cukup antusias ketika mendengar bahwa di Perpustakaan UIterdapat layanan-layanan tersebut. Bahkan para informan menyatakan bahwa mereka cukup takjub dengan adanya layanan penelusuran informasi yang telah dijelaskan oleh peneliti sebelumnya, karena dengan adanya layanan tersebut pengguna dapat melakukan konsultasi secara mendalam dengan pustakawan referensi terkait tugas perkuliahan atau pun penelitian mereka.

"Iya menurut saya layanan itu sangat bagus, karena kita kan terkadang gak dapat nyari berdasarkan judul buku aja tuh, terkadang kita butuh konsultasi mendalam juga terkait penelitian kita, dan biar nanti dapat dicarikan yang paling sesuai sumbernya, saya kemungkinan akan pakai layanan itu nanti.." (Mahli, wawancara, Maret 9, 2017)

"Oalaah bagus banget saya baru tahu ada layanan itu, saya memang lagi butuh jasa buat konsultasi terkait penelitian saya nih, karena saya masih bingung tentang penelitian saya ini.." (Yara, wawancara, Maret 9, 2017)]

"Intinya kalau menurut saya sih semua layanan yang ada di Perpustakaan UI itu sudah cukup baik bahkan lebih baik dari perpustakaan lain" (Yara, wawancara, Maret 9, 2017) 
“Wah menurut saya layanan itu sangat membantu ya, karena mencari sumber informasi itu cukup sulit ya, makanya kalau ada layanan itu sangat bagus sekali" (Raput, wawancara, Maret 9, 2017)

Berdasarkan jawaban informan di atas, mereka menyatakan bahwa layanan referensi dapat membantu pengguna dalam hal mencari sumber informasi yang sesuai dengan kebutuhan mereka melalui konsultasi mendalam dengan pustakawan referensi yang dalam hal ini disebut sebagai asisten pribadi mereka. Pernyataan tersebut sesuai dengan yang dikatakan oleh Ogibuiyi (2015) yang menyatakan bahwa layanan referensi juga dapat diartikan sebagai asisten personal yang bertugas untuk membantu dan memberikan bimbingan kepada pengguna dalam mencari informasi di perpustakaan agar pengguna mendapatkan informasi yang relevan dan sesuai dengan kebutuhan mereka (Ogibuiyi, 2015).

Selain itu peneliti menangkap sebuah makna dari perkataan yang diucapkan oleh pengguna bahwa sebenarnya pengguna sangat membutuhkan layanan referensi yang telah dijabarkan oleh peneliti, hanya saja mereka tidak tahu keberadaan layananlayanan tersebut. Hal itu dapat terlihat dari kata-kata informan lainnya yang menyatakan bahwa dirinya masih sangat kesulitan dalam mencari referensi ilmiah yang sesuai dengan kebutuhannya. Bahkan Ia pernah mencari ke perpustakaan lain karena informasi yang dicari tidak ada di Perpustakaan UI.

“..jujur, layanan itu dapat sangat membantu mahasiswa kayak kita gini yang terkadang masih kesulitan untuk dapetin sumber informasi yang kita butuhkan. Apa lagi untuk mahasiswa yang lagi nyusun skripsi kayak saya gini.." (Yara, wawancara, Maret 9, 2017)

"waktu itu saya pernah nyari sumber tapi tidak ketemu, bahkan saya juga sudah ke perpus kimia namun yang saya cari ngga ada. Kalau pun ada, saya harus bayar per lembarnya karena harus di fotokopi filenya. Kalo tau ada jasa Itu di perpus UI, saya tanya aja ke mereka" (Yara, wawancara, Maret 9, 2017)

Pernyataan ini sesuai dengan yang diungkapkan oleh Stuart Hall mengenai representasi melalui pendekatan reflective yang lebih menekankan apakah bahasa telah mampu mengekspresikan makna yang terkandung dalam objek yang bersangkutan (Hall, 1997). Dalam hal ini, Yara telah mengekspresikan bahwa dirinya sangat membutuhkan layanan referensi jika dilihat dari pengalamannya saat kesulitan dalam mencari sumber referensi untuk penelitiannya.

Pernyataan tersebut juga didukung dengan yang dikatakan oleh Qamariyah (2015) yang menyatakan bahwa tujuan utama dari layanan referensi adalah untuk memudahkan pengguna dalam mendapatkan informasi secara cepat seiring dengan berkembangnya teknologi, informasi dan komunikasi. Di sini dapat dilihat bahwa mahasiswa S1 khususnya semester akhir sangat membutuhkan layanan referensi untuk mendapatkan informasi secara cepat dan tepat.

Selain itu, penelitian ini juga menanyakan kepada semua informan apakah layanan referensi yang sudah diketahui oleh mereka dapat menjadi sebuah representasi dari Perpustakaan UI. Mereka semua setuju karena layanan referensi yang ada di Perpustakaan UI 
tersebut sangat inovatif dan berbeda dari perpustakaan mana pun.

"Harusnya bisat sih, karena ngga cuma dari UI aja, temen-temen gue dari luar pun banyak banget yang dateng kesini karena koleksinya yang lengkap melebihi dari perpustakaan mana pun" (Yara, wawancara, Maret 9, 2017)

"Menurut gue sih sangat bisa ya, tapi ya itu kalo gue tanyain temen-temen gue pun mereka juga kayaknya gatau deh ada layanan-layanan yang tadi lo sebutin itu" (Ida, wawancara, Maret 10, 2017)

"Seharusnya sih bisa ya, karena kan tujuan kita datang ke perpustakaan itu kan untuk mencari sumber ya, nah dengan adanya layanan tersebut tentunya akan sangat memudahkan kita dalam mencari sumber informasi yang kita butuhkan. Dan di Perpustakaan UI saya rasa semuanya sudah tersedia" (Raput, wawancara, Maret 9, 2017)

Pernyataan di atas sesuai dengan yang diungkapkan oleh Stuart Hall (1997) pada pendekatan intentional. Hall mengatakan bahwa pendekatan ini melihat bahwa bahasa dan fenomenanya dipakai untuk mengatakan maksud dan memiliki pemaknaan atas pribadinya. Ia tidak merefleksikan tetapi ia berdiri atas dirinya dengan segala pemaknaannya (Hall, 1997). Jadi dalam pendekatan intensional ini, lebih ditekankan pada apakah bahasa telah mampu mengekspresikan apa yang komunikator maksudkan. Pada Intinya informan dalam penelitian ini telah mampu mengekspresikan pendapat mereka terkait layanan referensi Perpustakaan UI, dan mereka sepakat bahwa layanan referensi tersebut dapat dijadikan sebagai representasi dari Perpustakaan UI.

\section{SIMPULAN}

Layanan referensi Perpustakaan UI dapat dikatakan sebagai representasi dari perpustakaan perguruan tinggi dengan melihat persepsi pengguna terkait eksistensi dari layanan referensi yang ada di Perpustakaan UI. Pengguna yang datang ke Perpustakaan UI sebenarnya mengetahui keberadaan layanan referensi yang dimiliki oleh Perpustakaan UI, namun tidak semuanya sudah pernah mereka gunakan. Berdasarkan hasil wawancara, informan mahasiswa dalam penelitian ini mengatakan bahwa tujuan mereka datang ke Perpustakaan UI adalah untuk mencari sumber referensi yang mereka butuhkan dengan cara mengakses layanan referensi di Perpustakaan UI. Sehingga, walaupun beberapa pengguna di Perpustakaan UI secara eksplisit masih belum mengetahui keberadaan semua layanan referensi khususnya layanan penelusuran informasi dan layanan referensi elektronik, namun layanan referensi tetap dapat dijadikan representasi dari Perpustakaan UI jika dilihat dari persepsi mereka yang sangat membutuhkan layanan referensi.

Perpustakaan UI juga telah menerapkan strategi kerja sama baik dengan bidang IT dalam menghadirkan inovasi terhadap layanan referensi, kemudian kerja sama di bidang repositori institusi, dan juga strategi kerja sama yang dilakukan oleh pustakawan referensi dalam melakukan promosi perpustakaan untuk mendukung layanan referensi menjadi representasi dari Perpustakaan UI. Selain itu juga Perpustakaan UI memiliki pustakawan referensi yang selalu ditingkatkan kompetensinya melalui pelatihan-pelatihan yang diberikan oleh Perpustakaan UI setiap tahunnya. Meski 
demikian, Perpustakaan UI dianggap masih kurang dalam memperkenalkan layanan referensi mereka kepada mahasiswa S1 khususnya. Berdasarkan hasil wawancara, mereka hanya diperkenalkan beberapa layanan yang ada di perpustakaan pada saat OBM saja, sehingga ketika mereka sudah semester akhir dan ingin menyusun penelitian, mereka sudah lupa dan tidak memanfaatkan beberapa layanan referensi lainnya yang dimiliki oleh Perpustakaan UI. Padahal beberapa dari mereka terutama mahasiswa yang sedang menyusun penelitian akan menggunakan layanan penelusuran dan layanan referensi elektronik ini jika dari awal mereka mengetahui keberadaan dari kedua layanan tersebut. Karena layanan penelusuran informasi dan layanan referensi elektronik merupakan inti dari layanan referensi yang sesungguhnya untuk dapat membantu mereka dalam hal melakukan konsultasi mendalam terkait penelitian mereka dengan pustakawan referensi disana.

\section{DAFTAR PUSTAKA}

Creswell, J.W. (2010). Research design: pendekatan kualitatif, kuantitatif dan mixed (ed. 3). Yogyakarta: Pustaka Pelajar

Fibriyanti, Y., \& Murtiningsih, T.W.H. (2013). Efektivitas pemanfaatan layanan perpustakaan sekolah oleh siswa kelas VIII th. ajaran 2013/2014 SMPN 2 Kerjo Kab. Karanganyar. Jurnal Ilmu Perpustakaan, 2(4), 41-48.

Gani, F. (2010). Representasi dan citra pustakawan: ikon, simbol, dan indeks. Februari 12, 2017. http:/ / dir.unikom.ac.id/prosiding/jbp tunikompp-gdl-fuadganide-23939/1simbol.pdf/pdf/1-simbol.pdf.
Hall, S. (2013). Representation: cultural representation and signifying practices. London: Sage Publication

Husna, H., \& Rahmah, E. (2015). Evaluasi layanan referensi di badan perpustakaan dan kearsipan provinsi sumatera barat. Jurnal Ilmu Informasi Perpustakaan dan Kearsipan, 4(1), 289296.

Idrus, M. (2009). Metode penelitian ilmu sosial. Yogyakarta: Erlangga.

Mulyati \& Rohanda. (2011). Persepsi mahasiswa terhadap kualitas pelayanan referensi di UPT Perpustakaan Unpad. Jurnal Kajian Ilmu Perpustakaan, 3(1), 111-120.

Kalsum, U. (2016). Referensi sebagai layanan, referensi sebagai tempat: sebuah tinjauan terhadap layanan referensi di perpustakaan perguruan tinggi. Iqra': Jurnal Perpustakaan dan Informasi, 10(1), 132-146.

Lasi, E.S. (2012). Analisis kepuasan pengguna layanan referensi melalui $e$ mail di perpustakaan universitas Surabaya. Jurnal Perpustakaan Pertanian. 21(1). 1-9.

Maryulisman. (2016). Layanan referensi di pusat perpustakaan UIN Syarif Hidayatullah Jakarta. Al-Maktabah, 15(1), 111-116.

Nuha, U. (2014). Meningkatkan kualitas pelayanan perpustakaan dengan pendekatan bilingual. Libraria, 2(1), 6079.

Rahmi, L., Tamara, A.S., \& Indira, I. (2016). Di balik wajah perkembangan layanan referensi pada perpustakaan perguruan tinggi. Record and Library Journal, 2(2), 105-118. 
Rangkuti, L.A. (2016). Pentingnya pendidikan pemakai (user education) di perpustakaan perguruan tinggi. Iqra': Jurnal Perpustakaan dan Informasi, 8(1), 40-47.

Reference of User Services Association. (2017). Reference and user services association: guidelines for implementing and maintaining virtual reference service. http://www.ala.org/rusa/resources/g uidelines/virtrefguidelines.

Sukaesih \& Rohman, A.S. (2013). Literasi informasi pustakawan: studi kasus di universitas padjadjaran. Jurnal Kajian Ilmu Perpustakaan, 1(1). 61-72.

Sulastri, S. (2013). Pengaruh informasi website perpustakaan terhadap sikap mahasiswa. Jurnal Kajian Ilmu Perpustakaan, 1(2). 171-177.

Sulistyo-Basuki. (2010). Metode penelitian. Jakarta: Penaku.

Tyasmara, N.C. (2016). Peningkatan layanan rujukan: upaya pembentukan citra layanan rujukan sebagai representasi perpustakaan perguruan tinggi. http:/ /lib.ui.ac.id/detail.jsp?id=204359 88\&lokasi=lokal.

Yin, R.K. (2011). Studi kasus: desain dan metode. Jakarta: Raja Grafindo Persada

Zubaidah, S. (2008). Pelayanan referensi perpustakaan perguruan tinggi. Iqra': Jurnal Perpustakaan dan Informasi, 2(1), 19. 
